\title{
Tolerance of Hardy Ferns to Selected Preemergence Herbicides
}

\author{
Glenn B. Fain ${ }^{1}$, Charles H. Gilliam² ${ }^{2}$ and Gary J. Keever ${ }^{2}$
}

ADDITIONAL INDEX WORDS. Arachniodes simplicior 'Variegata,' Cyrtomium falcatum 'Rochfordianum,' Dryopteris erytbrosora, Dryopteris ludoviciana, isoxaben, oryzalin, oxadiazon, oxyfluorfen, pendimethalin, prodiamine, trifluralin

Summary. Hardy ferns are widely grown for use in the landscape. The 1998 National Agricultural Statistics Services census of horticulture reported production of hardy/garden ferns at 3,107,000 containers from over 1200 nurseries. There is little research on herbicide use in hardy ferns, and herbicides that are labeled for container production are not labeled for use on hardy ferns. Studies were conducted to evaluate the tolerance of variegated east indian holly fern (Arachniodes simplicior 'Variegata'), tassel fern (Polystichum polyblepharum), autumn fern (Dryopteris erythrosora), rochford's japanese holly fern (Cyrtomium falcatum 'Rochfordianum'), and southern wood fern (Dryopteris ludoviciana), to applications of selected preemergence applied herbicides. Herbicides evaluated included selected granular or liquid applied preemergence herbicides. Spray-applied herbicides were pendimethalin at 3.0 or $6.0 \mathrm{lb} / \mathrm{acre}$, prodiamine at $\mathbf{1 . 0}$ or $2.0 \mathrm{lb} /$ acre, isoxaben at $\mathbf{1 . 0}$ or $2.0 \mathrm{lb} /$ acre, and prodiamine + isoxaben at $\mathbf{1 . 0}$ $+1.0 \mathrm{lb} /$ acre. Granular-applied herbicides were pendimethalin at 3.0 or 6.0 $\mathrm{lb} /$ acre, prodiamine at 1.0 or $2.0 \mathrm{lb} /$ acre, oxadiazon + prodiamine at $1.0+0.2$ or $2.0+0.4 \mathrm{lb} /$ acre, oxyfluorfen + oryzalin at $2.0+1.0$ or $4.0+2.0 \mathrm{lb} / \mathrm{acre}$, trifluralin + isoxaben at $2.0+0.5$ or $4.0+1.0 \mathrm{lb} / \mathrm{acre}$, oxadiazon at 4.0 or 8.0 $\mathrm{lb} / \mathrm{acre}$, and oxadiazon + pendimethalin at $2.0+1.25$ or $4.0+2.5 \mathrm{lb} /$ acre. The greatest reduction in growth of autumn fern was observed with the high rates of oxadiazon, oxadiazon + pendimethalin, and oxadiazon + prodiamine. Reductions in rochford's japanese holly fern growth were most severe when plants were treated with the high rate of trifluralin + isoxaben resulting in a $66 \%$ and $72 \%$ decrease in frond length and frond number, respectively. There were also reductions in frond length and number of fronds when treated with the high rate of oxadiazon + pendimethalin. There were no reductions in frond numbers on tassel fern with any herbicides tested. However, there were reductions in frond length from four of the $\mathbf{1 0}$ herbicides evaluated. The most sensitive fern to herbicides evaluated in 2004 was variegated east indian holly fern with reductions in frond length and number of fronds with four of the 10 herbicides tested. Southern wood fern appeared to be quite tolerant of the herbicides tested with the exception of the high rate of oxadiazon. Granular prodiamine proved to be a safe herbicide for all species tested in both 2004 and 2005. In 2005 all plants from all treatments were considered marketable by the end of the study. The durations of both studies were over 120 days giving adequate time for any visual injury to be masked by new growth. However, there was significant visual injury observed on the rochford's japanese holly fern treated with isoxaben at 60 and 90 days after treatment, which might reduce their early marketability.

$\mathrm{O}$ ver the past decade there has been increasing popularity of herbaceous perennials, including hardy ferns. This popularity has led to an increasing number of producers and numbers of plants produced. The National Agricultural Statistics Services 1998 census of horticulture reported wholesales sales hardy/garden ferns at 3,107,000 containers (U.S. Department of Agriculture, 2001). Weed

${ }^{1}$ USDA-ARS, Southern Horticultural Laboratory, P.O. Box 287, Poplarville, MS 39470. Mention of trade names or commercial products in this article is solely for the purpose of providing specific information and does not imply recommendation or endorsement by the U.S. Department of Agriculture.

${ }^{2}$ Department of Horticulture, 101 Funchess Hall, Auburn University, AL 36849. control is always a top priority for growers due to potential growth reduction from weed competition for moisture, nutrients, and light. Container nurseries provide an optimal environment for weed growth with frequent overhead irrigation and fertilizer applications. Fretz (1972) reported that in 2.5-qt nursery containers, one plant each of redroot pigweed (Amaranthus retroflexus) and large crabgrass (Digitaria sanguinalis) reduced the dry weight of japanese holly (Ilexcrenata) by $47 \%$ and $60 \%$, respectively. Research on perennial crops has shown significant reductions in growth and or marketability of plants due to weed infestations (Gibson, 1985; Staats et al., 1998).

Some form of weed control is necessary with effectiveness, crop tolerance, and cost primary considerations in selecting control programs. Nurseries reported spending as much as $\$ 4000 /$ acre per year to manually remove weeds in containers (Mathers, 2003). In 1974, cost to hand weed 1 acre of containers was reported to be $\$ 3600$ (Weatherspoon and Currey, 1975). In comparison, it was reported in 1990 that total cost for three applications of oxyfluorfen + oryzalin (Rout; Scotts-Sierra Crop Protection Co., Marysville, Ohio), was about $\$ 566$ /acre with labor for hand weeding of uncontrolled weeds adding another \$256-\$567/acre, resulting in a total cost for weed control of about \$812-\$1133/acre (Gilliam et al. 1990). In North Carolina, it was reported that without herbicide applications it may cost as much as \$1367 to hand weed 10003 -qt containers over a 4-month period based on an hourly wage of $\$ 14.75$, an average labor cost provided by local nurseries (Darden and Neal, 1999). In this study even marginally effective herbicides reduced hand weeding time and costs while the most effective herbicides reduced costs of hand weeding over 95\%. Herbicides are widely used in nursery production primarily due to their efficacy and cost effectiveness. Many studies have investigated the use of preemergence herbicides on various perennials with varying degrees of crop tolerance depending on herbicide and plant species (Calkins et al., 1996; Derr, 1994; Porter, 1996; Skroch et al., 1990; Staats and Klett, 1993).

None of the herbicides in this study are labeled for use on the fern species tested. Furthermore, little research

\begin{tabular}{llll}
\hline $\begin{array}{l}\text { Units } \\
\begin{array}{l}\text { To convert U.S. to SI, } \\
\text { multiply by }\end{array}\end{array}$ & U.S. unit & SI unit & $\begin{array}{l}\text { To convert SI to U.S., } \\
\text { multiply by }\end{array}$ \\
\hline 0.4047 & acre $(\mathrm{s})$ & $\mathrm{ha}$ & 2.4711 \\
2.54 & inch $(\mathrm{es})$ & $\mathrm{cm}$ & 0.3937 \\
1.1209 & $\mathrm{lb} / \mathrm{acre}^{-1}$ & $\mathrm{~kg} \cdot \mathrm{ha}^{-1}$ & 0.8922 \\
0.5933 & $\mathrm{lb} / \mathrm{yard}^{3}$ & $\mathrm{~kg} \cdot \mathrm{m}^{-3}$ & 1.6856 \\
6.8948 & $\mathrm{psi}$ & $\mathrm{kPa}$ & 0.1450 \\
0.9464 & $\mathrm{qt}$ & $\mathrm{L}$ & 1.0567
\end{tabular}


has been conducted on herbicide use in container-grown ferns. Lauderdale et al. (1993) evaluated the tolerance of container-grown rockford's japanese holly fern and autumn fern to selected granular and spray-applied herbicides. Dithiopyr at $4.0 \mathrm{lb} /$ acre caused significant injury to both autumn fern and rockford's japanese holly fern while granular trifluralin + isoxaben at $4.0+1.0 \mathrm{lb} /$ acre caused significant injury to rochford's japanese holly fern but not to autumn fern. Previous research identified many herbicides that reduced yield or did not control weeds in ground beds of leatherleaf fern (Rumobra adiantiformis) (Poole, 1979; Poole and Waters, 1974). Other work in leatherleaf fern ground beds has shown that metolachlor or alachlor applied every 2 months at 2.0, 4.0, and $8.0 \mathrm{lb} /$ acre or the same rate of oxadiazon applied every 4 months did not reduce the quality or quantity of fern fronds over a 28-month period (Stamps and Poole, 1987). Stamps (1992; 1993) also reported that granular prodiamine applied at 2.0,4.0, and $6.0 \mathrm{lb} /$ acre could safely be used in leatherleaf fern ground beds. The objective of this study was to determine the effects of selected preemergence herbicides on growth of five containergrown hardy fern species.

\section{Materials and methods}

Experiments were conducted in 2004 and 2005 evaluating the tolerance of hardy ferns to selected preemergence applied herbicides. On 13 July 2004 uniform liners of five hardy fern cultivars were transplanted from 72 cell flats into 3 -qt containers. Plants were placed under $80 \%$ shade in an open air shade structure at the $\mathrm{Pa}$ terson Greenhouse Complex, Auburn University, Ala. Plants received 0.25 inch water twice daily via overhead irrigation. Substrate used was pine bark: sand 7:1 (vol/vol) amended with 16.0 $\mathrm{lb} /$ yard $^{3}$ Polyon 16-6-12 (16N-2.6P10K; Pursell Technologies, Sylacauga, Ala), $5.0 \mathrm{lb} /$ yard $^{3}$ dolomitic lime and $1.5 \mathrm{lb} /$ yard $^{3}$ Micromax (The Scotts Co., Marysville, Ohio). Ferns evaluated were: variegated east indian holly fern, tassel fern, autumn fern, rochford's japanese holly fern, and southern wood fern. On the same day as potting all containers received an initial irrigation of 0.5 inch. Treatments were applied the following day to dry foliage. Treatments consisted of selected granular or liquid applied preemergence herbicides at the standard label rate and twice that rate as well as a hand weeded control. Spray-applied herbicides were pendimethalin (Pendulum 3.8 Aquacap; BASF Corp., Research Triangle Park, N.C.) at 3.0 or $6.0 \mathrm{lb} /$ acre, prodiamine (Barricade 4L; Syngenta Crop Protection, Inc. Greensboro, N.C.) at 1.0 or $2.0 \mathrm{lb} /$ acre, isoxaben (Gallery 75DF; Dow AgroSciences LLC, Indianapolis) at 1.0 or $2.0 \mathrm{lb} /$ acre, and prodiamine + isoxaben at $1.0+1.0 \mathrm{lb} /$ acre. Granularapplied herbicides were pendimethalin (Pendulum 2G; BASF Corp.) at 3.0 or $6.0 \mathrm{lb} /$ acre, prodiamine (RegalKade G; Regal Chemical Co., Alpharetta, Ga.) at 1.0 or $2.0 \mathrm{lb} /$ acre, oxadiazon + prodiamine (RegalStar G; Regal Chemical Co.) at $1.0+0.2$ or $2.0+0.4 \mathrm{lb} / \mathrm{acre}$, oxyfluorfen + oryzalin (Rout; The Scotts Co.) at $2.0+1.0$ or $4.0+2.0$ $\mathrm{lb} /$ acre, trifluralin + isoxaben (Snapshot $2.5 \mathrm{TG}$; Dow AgroSciences) at $2.0+$ 0.5 or $4.0+1.0 \mathrm{lb} /$ acre, oxadiazon (Ronstar G; Bayer Environmental Science, Montvale, N.J.) at 4.0 or $8.0 \mathrm{lb} /$ acre, and oxadiazon + pendimethalin (Kansel+; The Scotts Co.) at $2.0+1.25$ or $4.0+2.5 \mathrm{lb} /$ acre. Granular herbicides were applied using a hand held shaker while liquid formulations were applied using a $\mathrm{CO}_{2}$ backpack sprayer calibrated to deliver $30 \mathrm{gal} /$ acre at 28 psi using an flat fan nozzle (TeeJet DG8003VS; Spraying Systems Co., Wheaton, Ill.). Plants were arranged in a completely randomized design within species with six replications except for the southern wood fern which had five replications.

Data collected were phytotoxicity ratings at $7,15,30,60$, and $90 \mathrm{~d}$ after treatment (DAT). Ratings were based on a 0 - 10 scale where $0=$ no injury and $10=$ dead plant ratings of 3 or above would be considered significant enough to prevent marketability. On 15 Nov. 2004 , the study was terminated with the recording of total number of fronds and length of the longest three fronds. Herbicide efficacy was not evaluated and all containers were maintained weed free with periodic hand weeding. For all data, herbicide treatments were compared to the control using a one-sided Dunnett's $t$ test (Dunnett, 1955). Frond count data were squareroot transformed prior to analysis with means from the non-transformed data reported (Zar, 1999).

On 2 June 2005 the study was

Table 1. Evaluation of various herbicides on growth of varigated east indian holly fern.

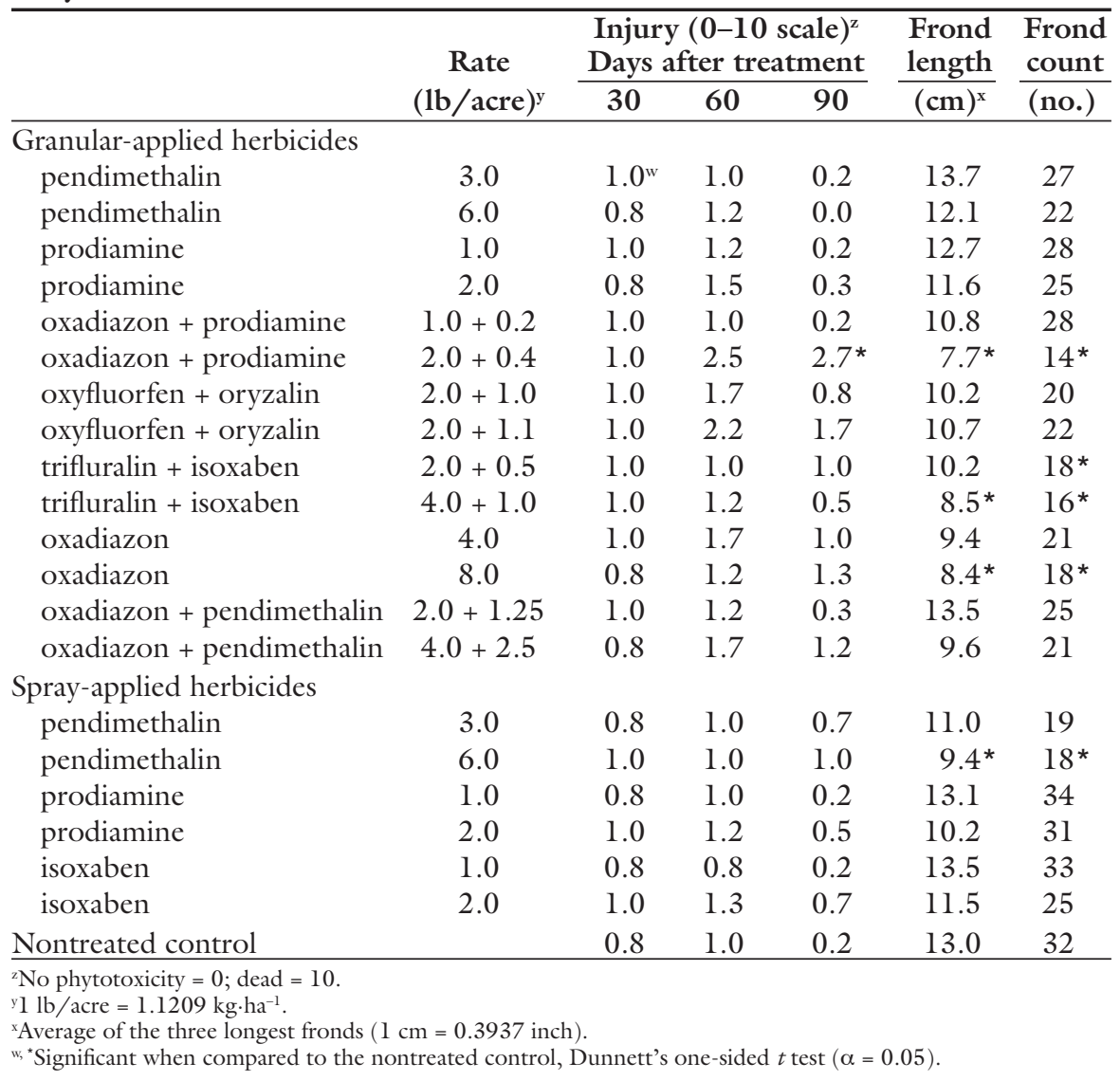


repeated on three (southern wood fern, rochford's japanese holly fern, and autumn fern) of the five species and four (granular-applied pendimethalin and prodiamine; spray-applied prodiamine and isoxaben) of the 10 herbicides, plus a combination of spray-applied prodiamine + isoxaben at $1.0+1.0$ $\mathrm{lb} /$ acre. Other materials and methods were the same as the first experiment with the exception of seven single plant replicates for each species/treatment combination and a study termination date of 7 Oct. 2005.

\section{Results and discussion}

In the 2004 experiment, visual phytotoxic symptoms were present $90 \mathrm{~d}$ after treatment on variegated east indian holly fern, autumn fern, and southern wood fern, treated with the high rates of oxadiazon + prodiamine, oxadiazon, and oxadiazon, respectively (Tables 1-3). Phytotoxic symptoms were also present on rochford's japanese holly fern at 90 DAT with the high rates of trifluralin + isoxaben and oxadiazon + pendimethalin (Table 5). In 2004 there was significant reduction in growth among all species with one or more of the herbicides evaluated (Tables 1-5). The most sensitive fern to herbicides evaluated in 2004 was variegated east indian holly fern with $28 \%$ to $41 \%$ reductions in frond length and a $44 \%$ to $50 \%$ reduction in number of fronds with the high rates of four of the 10 herbicides used elsewhere (Table 1).

When autumn fern was treated with the high rate of oxadiazon there was a $52 \%$ and $51 \%$ reduction in number of fronds and frond length, respectively (Table 2). When autumn fern were treated with both rates of oxadiazon + prodiamine there was a $34 \%$ to $43 \%$ reduction in number of fronds. Similar reductions in frond length were observed on autumn fern with the high rates of trifluralin + isoxaben and oxadiazon + pendimethalin. The least susceptible species to injury was southern wood fern where the only injury observed was from the high rate of oxadiazon (Table 3 ).

There was no reduction in number of fronds on tassel fern with any of the herbicides tested. However, there was a $21 \%$ to $41 \%$ reduction in frond length from 4 of the 10 herbicides evaluated (Table 4). Reduction in growth of rochford's japanese holly fern was most severe when plants were treated with trifluralin + isoxaben, resulting in a $54 \%$
Table 2. Evaluation of various herbicides on growth of autumn fern.

\begin{tabular}{|c|c|c|c|c|c|c|}
\hline & \multirow{2}{*}{$\begin{array}{c}\text { Rate } \\
(\text { lb/acre })^{y}\end{array}$} & \multicolumn{3}{|c|}{$\begin{array}{l}\text { Injury }(0-10 \text { scale })^{\mathrm{z}} \\
\text { Days after treatment }\end{array}$} & \multirow{2}{*}{$\begin{array}{c}\text { Frond } \\
\text { length } \\
(\mathrm{cm})^{\mathrm{x}}\end{array}$} & \multirow{2}{*}{$\begin{array}{l}\text { Frond } \\
\text { count } \\
\text { (no.) }\end{array}$} \\
\hline & & 30 & 60 & 90 & & \\
\hline \multicolumn{7}{|l|}{ Granular-applied herbicides } \\
\hline pendimethalin & 3.0 & $0.0^{\mathrm{w}}$ & 0.0 & 0.0 & 32.5 & 33 \\
\hline pendimethalin & 6.0 & 0.3 & 1.5 & 1.0 & 26.9 & 24 \\
\hline prodiamine & 1.0 & 0.0 & 0.0 & 0.0 & 36.5 & 32 \\
\hline prodiamine & 2.0 & 0.0 & 0.0 & 0.0 & 33.6 & 34 \\
\hline oxadiazon + prodiamine & $1.0+0.2$ & 0.0 & 0.0 & 0.2 & 33.9 & $23 *$ \\
\hline oxadiazon + prodiamine & $2.0+0.4$ & $1.3^{*}$ & $1.8^{*}$ & 1.2 & $23.1^{*}$ & 20 * \\
\hline oxyfluorfen + oryzalin & $2.0+1.0$ & 0.2 & 0.0 & 0.0 & 27.8 & 28 \\
\hline oxyfluorfen + oryzalin & $2.0+1.1$ & 0.2 & 0.5 & 0.0 & 28.3 & 27 \\
\hline trifluralin + isoxaben & $2.0+0.5$ & 0.2 & 0.0 & 0.0 & 31.3 & 31 \\
\hline trifluralin + isoxaben & $4.0+1.0$ & 0.2 & 0.8 & 1.0 & $21.9^{*}$ & 36 \\
\hline oxadiazon & 4.0 & 0.0 & 0.0 & 0.2 & 28.9 & 31 \\
\hline oxadiazon & 8.0 & $0.8^{*}$ & 1.3 & $2.7^{*}$ & $15.9^{*}$ & $18^{*}$ \\
\hline oxadiazon + pendimethalin & $2.0+1.25$ & 0.3 & 0.0 & 0.0 & 34.4 & 28 \\
\hline oxadiazon + pendimethalin & $4.0+2.5$ & 0.3 & 0.8 & 0.8 & $23.8^{*}$ & 25 \\
\hline \multicolumn{7}{|l|}{ Spray-applied herbicides } \\
\hline pendimethalin & 3.0 & 0.2 & 0.0 & 0.0 & 32.4 & 28 \\
\hline pendimethalin & 6.0 & 0.0 & 1.0 & 0.3 & 25.8 & 27 \\
\hline prodiamine & 1.0 & 0.2 & 0.2 & 0.0 & 34.5 & 45 \\
\hline prodiamine & 2.0 & 0.0 & 1.2 & 0.0 & 34.8 & 33 \\
\hline isoxaben & 1.0 & 0.2 & 0.0 & 0.0 & 31.4 & 32 \\
\hline isoxaben & 2.0 & 0.2 & 0.0 & 0.0 & 30.3 & 31 \\
\hline Nontreated control & & 0.0 & 0.0 & 0.0 & 32.9 & 35 \\
\hline
\end{tabular}

${ }^{2}$ No phytotoxicity $=0 ;$ dead $=10$.

yAverage of the three longest fronds $(1 \mathrm{~cm}=0.3937 \mathrm{inch})$.

${ }^{x} \mathrm{l} \mathrm{lb} / \mathrm{acre}=1.1209 \mathrm{~kg} \cdot \mathrm{ha}^{-1}$.

w, * * Significant when compared to the nontreated control, Dunnett's one sided $t$ test $(\alpha=0.05)$.

Table 3. Evaluation of various herbicides on growth of southern wood fern.

\begin{tabular}{|c|c|c|c|c|c|c|}
\hline & \multirow{2}{*}{$\begin{array}{c}\text { Rate } \\
(\text { lb } / \text { acre })^{y}\end{array}$} & \multicolumn{3}{|c|}{$\begin{array}{l}\text { Injury }(0-10 \text { scale })^{\mathrm{z}} \\
\text { Days after treatment }\end{array}$} & \multirow{2}{*}{$\begin{array}{l}\text { Frond } \\
\text { length } \\
(\mathrm{cm})^{x}\end{array}$} & \multirow{2}{*}{$\begin{array}{l}\text { Frond } \\
\text { count } \\
\text { (no.) }\end{array}$} \\
\hline & & 30 & 60 & 90 & & \\
\hline \multicolumn{7}{|l|}{ Granular-applied herbicides } \\
\hline pendimethalin & 3.0 & $1.0^{\mathrm{w}}$ & 0.6 & 2.0 & 42.2 & 19 \\
\hline pendimethalin & 6.0 & 1.0 & 0.6 & 0.2 & 36.3 & 15 \\
\hline prodiamine & 1.0 & 0.6 & 0.6 & 0.4 & 40.7 & 17 \\
\hline prodiamine & 2.0 & 0.2 & 0.0 & 0.2 & 38.5 & 15 \\
\hline oxadiazon + prodiamine & $1.0+0.2$ & 0.8 & 0.6 & 0.0 & 45.3 & 20 \\
\hline oxadiazon + prodiamine & $2.0+0.4$ & 0.8 & 1.0 & 0.2 & 41.5 & 17 \\
\hline oxyfluorfen + oryzalin & $2.0+1.0$ & 0.8 & 0.8 & 0.2 & 38.1 & 16 \\
\hline oxyfluorfen + oryzalin & $2.0+1.1$ & 0.6 & 1.0 & 0.6 & 35.2 & 15 \\
\hline trifluralin + isoxaben & $2.0+0.5$ & 1.0 & 0.8 & 0.6 & 38.7 & 24 \\
\hline trifluralin + isoxaben & $4.0+1.0$ & 0.8 & 0.6 & 0.6 & 40.7 & 16 \\
\hline oxadiazon & 4.0 & 0.8 & 0.2 & 0.0 & 48.5 & 20 \\
\hline oxadiazon & 8.0 & $1.6^{*}$ & $2.8^{*}$ & $2.2^{*}$ & $24.9^{*}$ & 17 \\
\hline oxadiazon + pendimethalin & $2.0+1.25$ & 1.1 & 0.6 & 0.8 & 36.4 & 22 \\
\hline oxadiazon + pendimethalin & $4.0+2.5$ & 0.6 & 1.8 & 1.0 & 31.2 & 16 \\
\hline \multicolumn{7}{|l|}{ Spray-applied herbicides } \\
\hline pendimethalin & 3.0 & 0.2 & 0.6 & 0.2 & 42.6 & 20 \\
\hline pendimethalin & 6.0 & 0.8 & 0.8 & 0.4 & 39.7 & 20 \\
\hline prodiamine & 1.0 & 1.2 & 0.4 & 0.0 & 37.3 & 18 \\
\hline prodiamine & 2.0 & 1.2 & 0.8 & 0.0 & 39.9 & 21 \\
\hline isoxaben & 1.0 & 0.6 & 0.6 & 0.2 & 39.8 & 21 \\
\hline isoxaben & 2.0 & 1.0 & 1.2 & 0.0 & 39.5 & 18 \\
\hline Nontreated control & & 0.4 & 0.2 & 0.0 & 41.5 & 19 \\
\hline
\end{tabular}

${ }^{2}$ No phytotoxicity $=0$; dead $=10$.

y $1 \mathrm{lb} /$ acre $=1.1209 \mathrm{~kg} \cdot \mathrm{ha}^{-1}$.

xAverage of the three longest fronds $(1 \mathrm{~cm}=0.3937$ inch $)$

${ }^{w},{ }^{*}$ Significant when compared to the nontreated control, Dunnett's one-sided $t$ test $(\alpha=0.05)$. 
Table 4. Evaluation of various herbicides on growth of tassel fern.

\begin{tabular}{|c|c|c|c|c|c|c|}
\hline & \multirow{2}{*}{$\begin{array}{c}\text { Rate } \\
(\text { lb/acre })^{y}\end{array}$} & \multicolumn{3}{|c|}{$\begin{array}{l}\text { Injury }(0-10 \text { scale })^{\mathrm{z}} \\
\text { Days after treatment }\end{array}$} & \multirow{2}{*}{$\begin{array}{l}\text { Frond } \\
\text { length }\end{array}$} & \multirow{2}{*}{$\begin{array}{l}\text { Frond } \\
\text { count } \\
\text { (no.) }\end{array}$} \\
\hline & & 30 & 60 & 90 & & \\
\hline \multicolumn{7}{|l|}{ Granular-applied herbicides } \\
\hline pendimethalin & 3.0 & $0.8^{\mathrm{w}}$ & 0.7 & 0.0 & 20.8 & 29 \\
\hline pendimethalin & 6.0 & $1.3^{*}$ & $2.7^{*}$ & 1.7 & $17.6^{*}$ & 25 \\
\hline prodiamine & 1.0 & 0.5 & 0.0 & 0.0 & 24.8 & 30 \\
\hline prodiamine & 2.0 & 1.2 & 0.5 & 0.3 & 23.7 & 35 \\
\hline oxadiazon + prodiamine & $1.0+0.2$ & 0.7 & 1.0 & 0.0 & 21.7 & 33 \\
\hline oxadiazon + prodiamine & $2.0+0.4$ & 0.5 & 0.5 & 0.0 & 21.7 & 34 \\
\hline oxyfluorfen + oryzalin & $2.0+1.0$ & 1.0 & $1.8^{*}$ & 0.2 & 20.4 & 29 \\
\hline oxyfluorfen + oryzalin & $2.0+1.1$ & 0.8 & 1.3 & 0.2 & 22.2 & 32 \\
\hline trifluralin + isoxaben & $2.0+0.5$ & 0.7 & 1.2 & 0.2 & $20.0^{*}$ & 33 \\
\hline trifluralin + isoxaben & $4.0+1.0$ & 0.8 & 1.5 & 1.0 & $16.3^{*}$ & 33 \\
\hline oxadiazon & 4.0 & 0.8 & 1.7 & 0.5 & $19.7^{*}$ & 40 \\
\hline oxadiazon & 8.0 & 0.5 & $2.0 *$ & 0.5 & 20.9 & 28 \\
\hline oxadiazon + pendimethalin & $2.0+1.25$ & 0.7 & 1.0 & 0.0 & 23.4 & 34 \\
\hline oxadiazon + pendimethalin & $4.0+2.5$ & 0.7 & $1.8^{*}$ & 0.8 & $18.3^{*}$ & 23 \\
\hline \multicolumn{7}{|l|}{ Spray-applied herbicides } \\
\hline pendimethalin & 3.0 & 0.5 & 0.3 & 0.0 & 24.5 & 32 \\
\hline pendimethalin & 6.0 & 0.8 & 0.7 & 0.2 & 22.7 & 31 \\
\hline prodiamine & 1.0 & 0.7 & 0.2 & 0.0 & 24.8 & 32 \\
\hline prodiamine & 2.0 & 0.3 & 0.3 & 0.0 & 24.6 & 34 \\
\hline isoxaben & 1.0 & 0.7 & 0.5 & 0.2 & 24.1 & 35 \\
\hline isoxaben & 2.0 & 0.7 & 0.8 & 0.0 & 25.6 & 38 \\
\hline Nontreated control & & 0.3 & 0.0 & 0.2 & 25.3 & 38 \\
\hline
\end{tabular}

${ }^{2}$ No phytotoxicity $=0$; dead $=10$.

yAverage of the three longest fronds $(1 \mathrm{~cm}=0.3937 \mathrm{inch})$.

${ }^{x} 1 \mathrm{lb} /$ acre $=1.1209 \mathrm{~kg} \cdot \mathrm{ha}^{-1}$.

w, " Significant when compared to the nontreated control, Dunnett's one sided $t$ test $(\alpha=0.05)$.

Table 5. Evaluation of various herbicides on growth of rochford's holly fern.

\begin{tabular}{|c|c|c|c|c|c|c|}
\hline & \multirow{2}{*}{$\begin{array}{c}\text { Rate } \\
(\text { lb } / \text { acre })^{y}\end{array}$} & \multicolumn{3}{|c|}{$\begin{array}{l}\text { Injury }(0-10 \text { scale })^{\mathrm{z}} \\
\text { Days after treatment }\end{array}$} & \multirow{2}{*}{$\begin{array}{l}\text { Frond } \\
\text { length } \\
(\mathrm{cm})^{\mathrm{x}}\end{array}$} & \multirow{2}{*}{$\begin{array}{l}\text { Frond } \\
\text { count } \\
\text { (no.) }\end{array}$} \\
\hline & & 30 & 60 & 90 & & \\
\hline \multicolumn{7}{|l|}{ Granular-applied herbicides } \\
\hline pendimethalin & 3.0 & $3.7^{\mathrm{w}}$ & 3.5 & 2.0 & 25.5 & 18 \\
\hline pendimethalin & 6.0 & $5.5^{*}$ & 4.7 & 0.7 & 24.7 & 16 \\
\hline prodiamine & 1.0 & 2.2 & 1.8 & 0.3 & 34.3 & 24 \\
\hline prodiamine & 2.0 & 3.2 & 2.8 & 0.2 & 31.8 & 23 \\
\hline oxadiazon + prodiamine & $1.0+0.2$ & 4.3 & 4.0 & 2.2 & 31.0 & 17 \\
\hline oxadiazon + prodiamine & $2.0+0.4$ & 4.5 & 3.8 & 1.2 & 29.2 & 21 \\
\hline oxyfluorfen + oryzalin & $2.0+1.0$ & $6.7^{*}$ & 3.8 & 0.8 & 28.7 & 19 \\
\hline oxyfluorfen + oryzalin & $2.0+1.1$ & $6.3^{*}$ & 4.8 & 1.7 & 28.7 & 19 \\
\hline trifluralin + isoxaben & $2.0+0.5$ & $5.2^{*}$ & $6.2^{*}$ & 2.3 & 23.5 & 18 \\
\hline trifluralin + isoxaben & $4.0+1.0$ & $5.2^{*}$ & $7.5^{*}$ & $4.8^{*}$ & $15.7^{*}$ & $7 *$ \\
\hline oxadiazon & 4.0 & 3.7 & 1.5 & 0.0 & 32.7 & 24 \\
\hline oxadiazon & 8.0 & $5.8^{*}$ & 3.7 & 0.5 & 31.4 & 20 \\
\hline oxadiazon + pendimethalin & $2.0+1.25$ & 3.7 & 1.8 & 0.3 & 34.4 & 25 \\
\hline oxadiazon + pendimethalin & $4.0+2.5$ & $5.2^{*}$ & $6.2^{*}$ & $3.1 *$ & $20.4^{*}$ & $10 *$ \\
\hline \multicolumn{7}{|l|}{ Spray-applied herbicides } \\
\hline pendimethalin & 3.0 & 2.8 & 2.5 & 0.0 & 34.8 & 22 \\
\hline pendimethalin & 6.0 & 3.2 & 1.8 & 0.5 & 33.8 & 25 \\
\hline prodiamine & 1.0 & 2.7 & 1.8 & 0.0 & 34.4 & 25 \\
\hline prodiamine & 2.0 & 3.2 & 2.5 & 0.7 & 32.1 & 21 \\
\hline isoxaben & 1.0 & 2.2 & 2.2 & 0.2 & 34.8 & 25 \\
\hline isoxaben & 2.0 & 2.5 & 1.5 & 0.3 & 34.4 & 22 \\
\hline Nontreated control & & 1.8 & 2.3 & 0.2 & 33.5 & 25 \\
\hline
\end{tabular}

${ }^{2}$ No phytotoxicity $=0$, dead $=10$.

${ }^{y} 1 \mathrm{lb} /$ acre $=1.1209 \mathrm{~kg} \cdot \mathrm{ha}^{-1}$.

${ }^{x}$ Average of the three longest fronds $(1 \mathrm{~cm}=0.3937$ inch $)$.

w, "Significant when compared to the nontreated control, Dunnett's one sided $t$ test $(\alpha=0.05)$. and $72 \%$ decrease in frond length and frond number, respectively (Table 5). There was also a reduction in frond length and number when treated with the high rate of granular oxadiazon + pendimethalin. In the 2005 experiment the only visual phytotoxic symptoms observed were with rockford's japanese holly fern treated with granular prodiamine or spray-applied isoxaben with symptoms still present at 90 DAT (Table 6).

In conclusion, results are similar to other studies that investigated the use of preemergence herbicides on herbaceous perennials with varying degrees of crop tolerance depending on herbicide and plant species (Calkins et al. 1996; Derr, 1994; Porter, 1996; Skroch et al., 1990; Staats and Klett, 1993). In 2004 the greatest reduction in growth of autumn fern was observed with oxadiazon + pendimethalin, oxadiazon, and oxadiazon + prodiamine all of which contain oxadiazon. In comparison, Stamps and Mathur (1982) reported no injury to leatherleaf fern grown in ground beds when treated with oxadiazon.

While all herbicides tested appeared to be safe on southern wood fern, especially in the 2004 study, tassel fern and rockford's japanese holly fern appear to be more sensitive. Granular prodiamineproved to be a safe herbicide for all species tested in both 2004 and 2005. Similarly, Stamps $(1992 ; 1993)$ also reported that prodiamine applied at $2.0,4.0$, or $6.0 \mathrm{lb} /$ acre could safely be used on leatherleaf fern in ground beds. Results from the 2004 study for variegated east indian holly fern and tassel fern indicate a sensitivity to several herbicides tested, most notably both rates of trifluralin + isoxaben. However, these species were not tested in the 2005 study; therefore results should not be considered conclusive.

In the 2005 study, all plants from all treatments were considered marketable by the end of the study. However, there was significant visual injury observed at 60 and 90 DAT on the rockford's japanese holly fern treated with isoxaben, which might reduce their early marketability.

\section{Literature cited}

Calkins, J.B., B.T. Swanson, and D.L. Newman. 1996. Weed control strategies for field grown herbaceous perennials. J. Environ. Hort. 14:221-227. 
Table 6. Evaluation of the phytotoxicity of various preemergence herbicides on three species of hardy ferns.

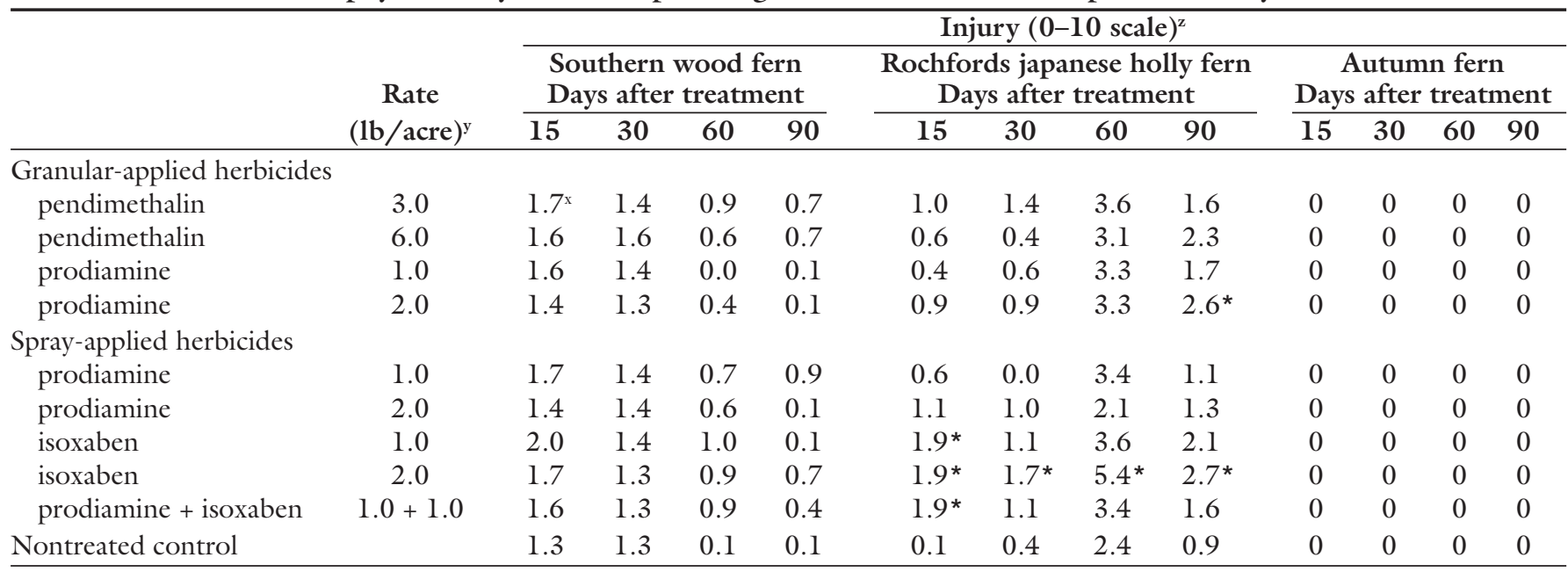

${ }^{2}$ No phytotoxicity $=0$; dead $=10$.

y $1 \mathrm{lb} /$ acre $=1.1209 \mathrm{~kg} \cdot \mathrm{ha}^{-1}$.

$x,{ }^{*}$ Significant when compared to the nontreated control, Dunnett's one-sided $t$ test $(\alpha=0.05)$.

Table 7. Evaluation of the effects of various preemergence herbicides on growth of three species of hardy ferns.

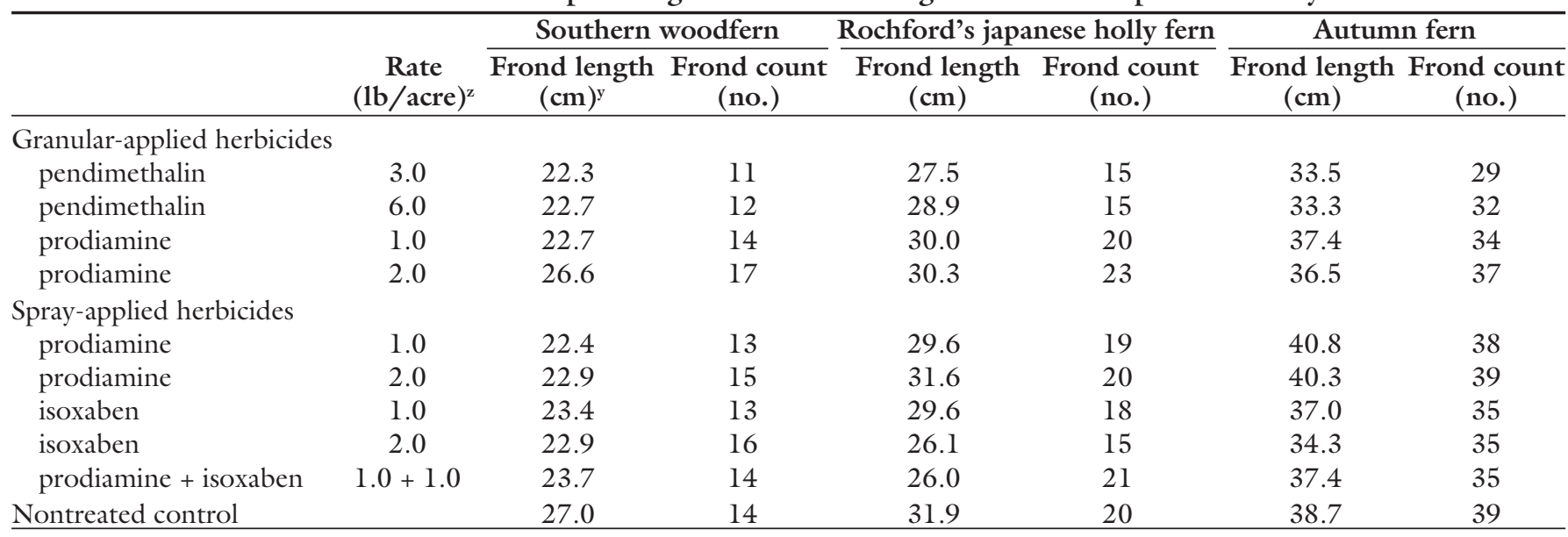

${ }^{2} 1 \mathrm{lb} /$ acre $=1.1209 \mathrm{~kg} \cdot \mathrm{ha}^{-1}$.

yAverage of the three longest fronds $(1 \mathrm{~cm}=0.3937$ inch $)$.

Darden, J. and J.C. Neal. 1999. Granular herbicide application uniformity and efficacy in container nurseries. Proc. Southern Nursery Assn. Res. Conf. 44:427-430.

Derr, J.F. 1994. Weed control in containergrown herbaceous perennials. HortScience 29:95-97.

Dunnett, C.W. 1955. A multiple comparison procedure for comparing several treatments with a control. J. Amer. Stat. Assn. 50:1096-1121.

Fretz, T.A. 1972. Weed competition in container grown japanese holly. HortScience 7:485-486.

Gibson,J.D. 1985 Research explores possibilities for container weed control. Amer. Nurseryman $162: 63,66-67$.

Gilliam, C.H., W.J. Foster, J.L. Adrian, and R.L. Shumack. 1990. A survey of weed control costs and strategies in container production nurseries. J. Environ. Hort. 8:133-135.

Lauderdale, D.M., C.H. Gilliam, and J.W. Olive. 1993. Evaluation of preemergence-applied herbicides on selected hardy ferns and hosta. Alabama Agr. Expt. Sta. Ornamental Res. Rpt. 8:28-29.

Mathers, H.M. 2003. Novel methods of weed control in containers. HortTechnology 13:28-31.

Poole, R.T. 1979. Influence of preemergence herbicides on weed control and yield of leatherleaffern, Rumobra adiantiformis. Proc. Trop. Reg. Amer. Soc. Hort. 23:2.

Poole, R.T. and W.E. Waters. 1974. Influence of several herbicides on yield of leatherleaf fern. Proc. Trop. Reg. Amer. Soc. Hort. 18:279-282.

Porter, W.C. 1996. Isoxaben and isoxaben combinations for weed control in container-grown herbaceous flowering perennials. J. Environ. Hort. 14:27-30.

Skroch, W.A., C.J. Catanzaro, and M.H. Yonce. 1990. Response of nine herbaceous perennials to selected herbicides. J. Environ. Hort. 8:26-28. Staats, D., D. Hillock, and J.E. Klett. 1998. Weed control and phytotoxicity of preemergence herbicides applied to container-grown herbaceous plants. HortTechnology 8:325-328.

Staats, D. and J.E. Klett. 1993. Weed control and phytotoxicity of preemergence herbicides to container-grown herbaceous and woody plants. J. Environ. Hort. 11:78-80.

Stamps, R.H. 1992. Prodiamine controlled florida betony (Stachys floridana) in leatherleaf fern (Rumobra adiantiformis). Weed Technol. 6:961-967.

Stamps, R.H. 1993. Prodiamine suppresses spreading dayflower (Commelina diffusa) facilitating hand-weeding in leatherleaf fern (Rumohra adiantiformis) ground beds. J. Environ. Hort. 11:93-95.

Stamps, R.H. and D.D. Mathur. 1982. Herbicides for weed control in leatherleaf fern. HortScience 17:201-203.

Stamps, R.H. and R.T. Poole. 1987. Herbicide effects during leatherleaf fern bed establishment. HortScience 22:261-264.

U.S. Department of Agriculture 2001. 1997 Census of agriculture, 1998 Census of horticulture specialties, Vol. 3, Special studies. Part 2. U.S. Dept. Agr. Natl. Agr. Stat. Serv., Washington, D.C.

Weatherspoon, D.M. and W.L. Currey. 1975. Evaluation of Treflan, Lasso, and Ronstar herbicides for use in woody ornamental nurseries. Proc. Fla. State Hort. Soc. 88:535-540.

Zar, J.H. 1999. Biostatistical analysis. Prentice Hall, Upper Saddle River, N.J. 